\title{
Analysis of 7P Marketing Mix Factors on Consumer Buying Interests Dodol Kawista Cap Dewa Burung in Rembang District
}

\author{
Abdillah Ulfaida Rahmawanti ${ }^{1}$, Sugiharti Mulya Handayani ${ }^{2 *}$, Setyowati ${ }^{3}$ \\ Agribusiness Studi Program, Faculty of Agriculture, Sebelas Maret University, St. Ir. Sutami 36 A, \\ Surakarta (57126), Indonesia
}

Received: 15 August 2020; Revised: 19 January 2021; Accepted: 27 January 2021

\begin{abstract}
Kawista is a typical plant in Rembang that can be proceseds into food products, known as dodol kawista. MSME Dewa Burung is a business process which processes kawista fruit into dodol to gain higher selling value. This study aims to determine the impact of the marketing mix on consumer buying interests and to determine the variables that have the most dominant effect. The research method used is descriptive and quantitative. Sample selection using accidental sampling method with 100 respondents. The location has chosen by the purposive method. This research used primary and secondary data with observational data collection techniques, interviews, and documentation. The data were analyzed using multiple linear regression analysis using SPSS version 25 . The results showed that individually variable products, places, people, processes, and physical evidence had a positive significant relationship on consumer's buying interests, while price and promotion variables had negative significant relationship. All variables have a significant relationship collectively with consumer buying interests and the most dominant variable in process.
\end{abstract}

Keywords: consumer; buying; interest; dodol; kawista

\section{How to cite:}

Rahmawanti, A. U., Handayani, S. M., \& Setyowati, S. (2021). Analysis of 7P Marketing Mix Factors on Consumer Buying Interests Dodol Kawista Cap Dewa Burung in Rembang District. HABITAT, 32(1), 47-53. https://doi.org/10.21776/ub.habitat.2021.032.1.6

\section{Introduction}

Kawista is one of the annual horticultural plants that can be found in Rembang, Central Java. Kawista (Limonia acidissima) is an endemic commodity (Pradana, 2017). The endemic means exclusively original at a place that has specific characteristics. Kawista can be processed to gain higher selling value than consumed directly. One of the products from kawista is dodol kawista.

Dodol kawista is one of the traditional foods which come from Rembang, Central Java. Traditional food has great potential when it concerns the quality of products. This potential can be used as a cultural and traditional promotion from its place by the authenticity of local food (Stadi et al., 2011). Traditional foods also have better health benefits (Adinolfi et al., 2011). Other potentials include: having a level of

${ }^{*}$ Correspondence Author.

E-mail: sugihartimulya@staff.uns.ac.id Telp: +62-856-2910301 safety by connecting quality attributes to food locality (Aggarwal et al., 2014), promote local communities, and can support rural development (Donner et al., 2017).

There is no denying that business competition is increasing recently. Manufacturers must work hard to be able to provide the best products to consumers. Therefore, manufacturers are required to create product with good quality (Purnamasari et al., 2018). Marketing strategy is important aspect because it helps to analyse how far the ability to attract consumers. It needs an effort through of a marketing program called the marketing mix (Nugroho and Dewanto, 2011). The concept of a marketing mix serves as a tool used by organizations to survive in a competitive environment (Owomoyela et al., 2013).

Buying interest has a considerable influence on consumer behavior to lead to what consumers will do next. Factors that affecting buying interest are related to person's feeling and emotion. Satisfaction after buying products or services will strengthen the buying interest, while 
dissatisfaction can eliminate the buying interest (Kukanja et al., 2016).

Scientific studies that discuss the importance of developing marketing on traditional foods to survive and remain loved by the community are still limited. Therefore, it is important to analyze factors that affect consumer buying interest in dodol kawista. If each region pay attention and develop its traditional food, this can make traditional food exist and increase regional income.

\section{Research Methodology}

The method of research used is descriptive and quantitative. Determination of the location of this study is purposively (intentionally). The location chosen is Rembang because kawista can be found easily, and some business processes kawista in Rembang. MSME Dewa Burung is a pioneer of processed products from kawista fruit.

Sample determination used the accidental sampling method with the number of 100 respondents. Respondents in the research are people who live in Rembang with criteria is ever purchase at least once. Dodol Kawista Cap Dewa Burung directly at the Dewa Burung Shop. The study used primary and secondary data with observational data collection techniques, interviews, and documentation.

The variable measurement used a Likert scale with four score levels that are very agreeable, agree, and disagree with the score of $4,3,2$, and 1 . The result of data from the Likert scale is transformed into quantitative data. The transformation process used MSI (Method of Successive Interval) using excel software. The data results were then analyzed using multiple linear regression analysis using SPSS version 25.

\subsection{Instrument Test}

Validity and reliability tests are used in the research instrument test with the number of 30 samples so that the research instruments can be accounted for. Validity and reliability test results are as follows:

a. Validity Test

The validity test using level of significant rate of 0.05 . Based on the provisions of the df, obtained $\mathrm{df}=28$ with $\mathrm{R}_{\text {table }}$ value 0.36 . Instruments in this study are indicated valid. All variables have shown $R_{\text {data }} \geq R_{\text {tabel }}$

b. Reliability Test
$\mathrm{R}_{\text {alpha }}$ value based of Cronbach's Alpha value is 0.890 . The result of the reliability test obtained $R_{\text {alpha }}(0.890) \geq R_{\text {table }}(0.361)$ so that all variables are indicated reliable.

\subsection{Classic Assumption Test}

To creat good data result, classic assumption tests are required. Classic assumption test that matches with the assumptions will resulting BLUE (Best Linear Unbiased Estimator) data.

\section{a. Normality Test}

Based on the P-Plot graph and Kolmogorov-Smirnov test obtained the results that the research data are normally-distributed. It is because normal-probability plots have the spread of dots around diagonal lines or follow the diagonal direction. Also, from the result of the Kolmogorov-Smirnov normality test asymp value Sig 0.20 greater than $\alpha$ value of 0.05 .

b. Multikollinearity Test

The results of multicollinearity test show no interrelation correlation or collinearity between independent variables. All variables have a VIF $<10$ or Tolerance $>0.01$.

c. Heteroskedasticity Test

The results of the Heteroskedasticity Scatterplot graph test obtained no heteroskedasticity on the regression model. This result was obtained from residual data that spreads randomly at points spread above and below the number 0 .

\subsection{Multiple linear regression models}

To measure the influence between independent variables against dependent variables used multiple linear regression equation models as follows:

$$
\begin{aligned}
\mathrm{Y}= & \mathrm{a}+\mathrm{b}_{1} \cdot \mathrm{X}_{1}+\mathrm{b}_{2} \cdot \mathrm{X}_{2}+\mathrm{b}_{3} \cdot \mathrm{X}_{3}+\mathrm{b}_{4} \cdot \mathrm{X}_{4}+\mathrm{b}_{5} \cdot \mathrm{X}_{5}+ \\
& \mathrm{b}_{6} \cdot \mathrm{X}_{6}+\mathrm{b}_{7} \cdot \mathrm{X}_{7}+e
\end{aligned}
$$

Description:

$\mathrm{Y}=$ Consumer buying interest

$\mathrm{a}=$ Constant

$\mathrm{X}_{1}=$ Variable of product

$\mathrm{X}_{2}=$ Variable of price

$\mathrm{X}_{3}=$ Variable of place

$\mathrm{X}_{4}=$ Variable of promotion

$\mathrm{X}_{5}=$ Variable of people

$\mathrm{X}_{6}=$ Variable of process

$\mathrm{X}_{7}=$ Variabel of physical evidence

$\mathrm{b}_{1}=$ Product regression coefficient 
$\mathrm{b}_{2}=$ Price regression coefficient

$b_{3}=$ Place regression coefficient

$\mathrm{b}_{4}=$ Promotion regression coefficient

$b_{5}=$ People regression coefficient

$\mathrm{b}_{6}=$ Process regression coefficient

$\mathrm{b}_{7}=$ Physical evidence regression coefficient

$$
e=\text { error }
$$

\subsection{Hyphothesis Test}

The hypothesis test to determine the influence of 7P marketing mix variables in this study are:

a. Coefficient of Determination Test

If the Adjusted R Square value is closer to

1 , indicates that independent variables can give an idea of the dependent variable to complete information (Riyanto and Hatmawan, 2020).

b. F-test

If the sig value $\leq \alpha$, then the independent variables collectively have a significant relationship with the dependent variable. If the sig value $>\alpha$, then the variables have no significant relationship collectively in the model (Riyanto and Hatmawan, 2020).

c. t-test

If the sig value $\leq \alpha$, then the independent variable individually has a significant relationship with the dependent variable. If the sig value $>\alpha$, then the variable has no significant relationship individually in the model (Riyanto and Hatmawan, 2020).

\section{d. Dominant Variable}

The dominant variable of independent can be seen from the value of the beta coefficient. If the Beta coefficient value is closer to 1 , then the relationship between dependent and independent variables is stronger (Aldy, 2017).

\section{Results and discussion}

\subsection{General Condition of Rembang District}

Astronomically, Rembang is located between $6^{\circ} 30^{\prime}-7^{\circ} 6^{\prime} \mathrm{LS}$ and $111^{\circ} 00^{\prime}-111^{\circ} 30^{\prime}$ BT that covering land areas of 101,408 ha and have sea with a coastline of $62.5 \mathrm{~km}$. Rembang has a dry climate type of $111.76 \%$ (BPS, 2020). This climate is suitable for kawista. Kawista good in adaptation with sandy soil areas and can grow well if planted in the coastal area (Dewi, 2013).

\subsection{General Condition of MSME Dewa Burung}

MSME Dewa Burung is a pioneer company in processed kawista fruit. This business has established in 1925 that has been producing lemonade, syrup, and dodol kawista. MSME Dewa Burung has the vision to continue to operate for a long time, and the products offered can be accepted by the community. Kawista Cap Dewa Burung shop has located on J1. P. Diponegoro 45 Rembang.

\subsection{Characteristics of respondents}

Characteristics of respondents can be seen in Table 1.

Tabel 1. Characteristics of Respondents

\begin{tabular}{ll}
\hline Characteristics & Respondents (\%) \\
\hline Gender & Female : $59 \%$ \\
& Male $: 41 \%$ \\
Age group & $20-25: 52 \%$ \\
& $26-35: 16 \%$ \\
& $36-45: 16 \%$ \\
& $46-55: 14 \%$ \\
& $56-65: 2 \%$ \\
Education & High School : $38 \%$ \\
attainment & Diploma : $8 \%$ \\
& Bachelor $: 41 \%$ \\
Professional & Master : $13 \%$ \\
activity & Active : $74 \%$ \\
& Unemployed: $2 \%$ \\
\hline
\end{tabular}

In Table 1 shown that female respondents have more percentage than male by $59 \%$. It is because dodol kawista has a sweet and slightly sour taste is preferred by females than male respondent. A study proves that added sugar intake is more common in females than men, so females prefer sweetness over men (Hallam et al., 2016). Most respondents were those aged 17-25. According to the Ministry of Health of the Republic of Indonesia, this age belongs to adolescent age. It becomes a potential target for businesses. Consumptive behavior is dominant among adolescents who are still easily affected by outside persuasion (Asri, 2012). The education level of the most respondents was Bachelor's degree of $41 \%$. Higher education will make a person think more critically to know many things like dodol kawista. Respondents who had more employment/active status were $74 \%$. Respondents who are working already have incomes, so they can manage their finances include buying dodol kawista. 
3.4. Analysis of The Influence of 7P Marketing Mix Factors on Consumer Buying Interests of Dodol Kawista Cap Dewa Burung

The results of influence analysis of $7 \mathrm{P}$ marketing mix factors on consumer buying interest dodol kawista can be seen in Table 2 .

Tabel 2. The Results of Influence Analysis 7P Marketing Mix Factors On Consumer Buying Interests Dodol Kawista Cap Dewa Burung

\begin{tabular}{lrc}
\hline \multirow{2}{*}{ Model } & \multicolumn{2}{c}{$\begin{array}{c}\text { Unstandardized } \\
\text { Coefificients }\end{array}$} \\
\cline { 2 - 3 } & \multicolumn{1}{c}{ B } & Std. Error \\
\hline (Constant) & 232,761 & 1325,436 \\
Product $\left(\mathrm{X}_{1}\right)$ & 0,214 & 0,089 \\
Price $\left(\mathrm{X}_{2}\right)$ & $-0,075$ & 0,103 \\
Place $\left(\mathrm{X}_{3}\right)$ & 0,206 & 0,093 \\
Promotion $\left(\mathrm{X}_{4}\right)$ & 0,016 & 0,075 \\
People $\left(\mathrm{X}_{5}\right)$ & 0,153 & 0,074 \\
Process $\left(\mathrm{X}_{6}\right)$ & 0,233 & 0,100 \\
Physical & 0,185 & 0,093 \\
evidence $\left(\mathrm{X}_{7}\right)$ & & \\
\hline
\end{tabular}

The regression model analysis of the influence of 7P marketing mix factors on consumer buying interest Dodol Kawista Cap Dewa Burung in this study is as follows:

$$
\begin{aligned}
\mathrm{Y}= & 232,761+0,214 \mathrm{X}_{1}-0,075 \mathrm{X}_{2}+0,206 \mathrm{X}_{3}+ \\
& 0,016 \mathrm{X}_{4}+0,153 \mathrm{X}_{5}+0,233 \mathrm{X}_{6}+0,185 \mathrm{X}_{7}+\mathrm{e}
\end{aligned}
$$

\subsection{Coefficient of Determination Test}

The result of Adjusted R Square has a value of 0.492 . Also, independent variables can explain the dependent variable that is the buying interest of Dodol Kawista Cap Dewa Burung $49 \%$. The remaining $51 \%$ influenced by other variables not included in the study model as though people's opinions and political power.

\subsection{F-test}

F-Test used to find out how much influence independent variables have on a dependent variable in global. The results of independent variables' values have a significant relationship with the dependent variable. It is because of the Ftest criteria that the sig value. $(0.000) \leq \alpha(0.05)$ then independent variables have a significant relationship.

The results are in line with the opinion that the marketing mix is a set of marketing tools that companies use to achieve marketing goals (Kotler, 2012). The marketing mix is a controlled variable that companies can use to influence consumers from a particular market segment. Besides, on the global of independent variables of marketing mix can develop Dewa Burung MSMEs to affect consumer buying interest in Dodol Kawista Cap Dewa Burung.

\section{7. t-test}

The result of t-test can be seen by Tabel 3 .

Tabel 3. Result of t-test

\begin{tabular}{lcc}
\hline \multicolumn{1}{c}{ Model } & \multicolumn{1}{c}{ t } & Sig. \\
\hline (Constant) & 0,176 & 0,861 \\
Product $\left(\mathrm{X}_{1}\right)$ & 2,398 & 0,018 \\
Price $\left(\mathrm{X}_{2}\right)$ & $-0,726$ & 0,470 \\
Place $\left(\mathrm{X}_{3}\right)$ & 2,221 & 0,029 \\
Promotion $\left(\mathrm{X}_{4}\right)$ & 0,211 & 0,833 \\
People $\left(\mathrm{X}_{5}\right)$ & 2,068 & 0,041 \\
Process $\left(\mathrm{X}_{6}\right)$ & 2,340 & 0,021 \\
Physical evidence $\left(\mathrm{X}_{7}\right)$ & 1,991 & 0,049 \\
\hline
\end{tabular}

3.7.1. The Effect of Product on Consumer Buying Interests Dodol Kawista Cap Dewa Burung

Product obtains a significance value of 0.018 so that the sig value $(0.018) \leq \alpha(0.05)$. It means that the product has a significant relationship with the buying interest of Dodol Kawista Cap Dewa Burung.

Dodol kawista Cap Dewa Burung has a unique packaging design and it is attractive, safe, and useful. Rundh (2010) argues that packaging can attract consumers' attention to a particular brand, improve the image and stimulate consumer perception of the product. Packaging also conveys the distinctive value of a product.

Consumer demand for traditional food caused by interest to search for the local authenticity of an area. It can be found by the taste of the product (Sims, 2010). The taste of dodol kawista is delicious, sweet, and has a strong kawista fruit flavor. The aroma of dodol kawista is very distinctive so that it makes consumers feel like consuming the original kawista fruit. Dodol kawista from endemic plants, many respondents choose to buy products for a gift, in addition to be consumed by themself or with family.

The shelf life of dodol kawista products can be up to three months. The process does not use preservatives. Traditional foods have health benefits due to their natural ingredient composition (Adinolfi et al., 2011). 


\subsubsection{The Effect of Price on Consumer Buying Interests Dodol Kawista Cap Dewa Burung}

The price obtains a significance value of 0.470 so that the sig value $(0.470)>\alpha(0.05)$. It means that price has no significant relationship with the buying interest of dodol kawista.

The price of Dodol Kawista Cap Dewa Burung has more expensive than other brands because Dodol Kawista Cap Dewa Burung has a better product quality so that there is price conformity with the quality of the product. Dodol Kawista Cap Dewa Burung is processed using a machine so that the testicles are smoother and the manufacturing process is faster. The operational cost caused by using technology such as electricity and maintenance costs also affects the price of Dodol Kawista Cap Dewa Burung more expensive. The results are in line with Halim and Iskandar's research (2019) that variable price have no significant relationship on consumer buying interest.

\subsubsection{The Effect of Place on Consumer Buying Interests Dodol Kawista Cap Dewa Burung}

The location obtains a signification value of 0.029 so that the sig value. $(0,029) \leq \alpha(0,05)$. It means that location has a significant relationship with the buying interest of Dodol Kawista Cap Dewa Burung. This result is in line with Wardani's research (2015) at the same product, businesses can be more successful if they are in the right or strategic location.

Dewa Burung shop has located in the mainline pantura. Pantura becomes a link among cities so that the buyers are not only from Rembang. The location on the mainline makes it easier to find by public transport. Dewa Burung Shop is close to tourist attractions such as Kartini Rembang Beach, R.A. Kartini Museum, Mangrove Forest Red Bridge tourism object, and many other beaches. Also, Purnomo (2016) argue that a strategic location is at the center of community activities and considered capable of experiencing economic growth.

\subsubsection{The Effect of Promotion on Consumer Buying Interests Dodol Kawista Cap Dewa Burung \\ The promotion obtains a significance value} of 0.833 so that the sig value $(0.833)>\alpha(0.05)$. It means that the promotion has no significant relationship with the buying interest of Dodol Kawista Cap Dewa Burung. The promotional media of MSME Dewa Burung is still inadequate.

MSME Dewa Burung used online media such as Web with an address in kawista.com. But the promotion by using this media is inneffective so, there is no significant increase in sales. The manager chooses promotion through expos and culinary festivals to support the activities of the Rembang City Government.

\subsubsection{The Effect of People on Consumer Buying Interests Dodol Kawista Cap Dewa Burung}

People obtain a significance value of 0.041 so that the sig value $(0.041) \leq \alpha(0.05)$. It means that people have a significant relationship with the buying interest of Dodol Kawista Cap Dewa Burung. Employees who are responsive, friendly, and quick in buying services at MSME Dewa Burung affect buying interests. Kotler's statement (2012) that the more positive service provided to consumers, the better the impact in making purchasing decisions.

Employees are always responsive in serving the consumer. The consumer who needs information will be explained by the employees so that consumers are feeling comfortable. Employees are self prepared to become consumer-friendly and understand all information about the products. In terms of cohesiveness from employees can be seen from discipline in uniform and neatness causing good perception by consumers.

\subsubsection{The Effect of Process on Consumer Buying Interests Dodol Kawista Cap Dewa Burung}

The process obtains a significance value of 0.021 with a sig value $(0.021) \leq \alpha(0.05)$. It means that process has a significant relationship with the buying interest of Dodol Kawista Cap Dewa Burung. According to Saragih's research (2012) the process has a significant relationship on buying interest. The whole work activity is a process.

The process of ordering, purchasing services, and product purchase transactions are simple and fast. The booking process can request by phone. Customers also allowed to check the products they want to buy to ensure that products are in good condition. The transaction directly with the cash register and the employee also double checking the product to provide the appropriate note. 


\subsubsection{The Effect of Physical Evidence on Consumer Buying Interests Dodol Kawista Cap Dewa Burung}

The physical evidence obtains a significance value of 0.049 so that the sig value $(0.049) \leq \alpha(0.05)$. It means that physical evidence has a significant relationship with the buying interest of Dodol Kawista Cap Dewa Burung. Saragih (2012) argues that physical evidence plays a large role in the presentation of the service. It can be obtained from parking lot, good buildings, the air inside the store is fresh and comfortable, also the beauty of the interior design. Good maintenance in all those aspects will make the higher of consumer's buying interest in the store.

Physical evidence is the trigger of consumer attraction. The manager renovated the building to look attractive and clean, arranging the purchase room so looks spacious and comfortable. The manager also pays attention to the air in the shop to keep it fresh by providing air conditioner in every corner of the room

\subsection{Dominant Variable}

Tabel 4. The Result of StandardizedCoefficients Beta Test

\begin{tabular}{lccc}
\hline Model & $\begin{array}{c}\text { Standardized } \\
\text { Coefficients } \\
\text { Beta }\end{array}$ & T & Sig. \\
\hline (Constant) & 0,203 & 0,176 & 0,861 \\
Product & $-0,069$ & $-0,726$ & 0,018 \\
Price & 0,203 & 2,221 & 0,029 \\
Place & 0,021 & 0,211 & 0,833 \\
Promotion & 0,194 & 2,068 & 0,041 \\
People & 0,223 & 2,340 & 0,021 \\
Process & 0,200 & 1,991 & 0,049 \\
Physical & & & \\
evidence & & & \\
\hline
\end{tabular}

Based on the Table 4 the value of the Standardized Coefficients Beta process has the highest value of 0.223 . It means the process has a dominant effect on the buying interest of Dodol Kawista Cap Dewa Burung by $22.3 \%$.

\section{Conclusion}

Based on the results can be concluded that product, place, people, process, and physical evidence have a significant relationship with buying interest. However, price and promotion have less significant relationship with buying interest. Independent variables globally have a significant-relationship with the buying interest of Dodol Kawista Cap Dewa Burung in Rembang District. The variable that has the dominant effect on the buying interest of Dodol Kawista Cap Dewa Burung in Rembang District is the process with a percentage of $22.3 \%$.

Knowing the model in defining the relationship between the 7P marketing mix and consumer buying interest, the writer would like to give several recommendations for MSME Dewa Burung. Related to variable prices and promotions. Improving promotion management on social media that is already used and adding social media to improve marketing. Price can be developed by sizing the variations on dodol kawista so the consumer can buy from cheap to expensive prices according to quantity.

\section{References}

Adinolfi, F., Rosa, M., and Trabalzi, F. (2011). Dedicated Andgeneric Marketing Strategies: The Disconnection Between Geographical Indications And Consumer Behavior In Italy. British Food Journal, 113(3),419-435.

Aggarwal, R., Singh, H., and Prashar, S. (2014). Branding of Geographical Indications In India: A Paradigm To Sustain Its Premium Value. International Journal of Law and Management, 56(6),431-442.

Aldy, R. (2017). Analisis Statistik Ekonomi dan Bisnis dengan SPSS. Ponorogo: UNMUH Ponorogo Press.

Asri, A. (2012). Pengaruh Kepercayaan Diri Terhadap Perilaku Konsumtif Pada Siswa Kelas XI SMA Negeri 1 Babelan. Jurnal Penelitian dan Pengukuran Psikologi, 1(1), 197-202.

BPS Kabupaten Rembang. (2020). Kabupaten Rembang Dalam Angka 2020. Rembang: Badan Pusat Statistik.

Dewi, R. (2013). Bioaktivitas Buah Kawista (Limonia acissidema) Bima dan Penentuan Sidik Jarinya Menggunakan Kromatografi Lapis Tipis. Skripsi. Institut Pertanian Bogor.

Donner, M., Fort, F., and Vellema, S. (2017). From Geographical Indications to Collective Place Branding in France and Morocco. In The Importance of Place: Geographical Indications as a Tool for Local and Regional Development. The 
Importance of Place (pp. 173-196) Switzerland: Springer Publishers.

Hallam, J., Boswell, R.G., Devito, E.E., and Kober, H. (2016). Gender-Related Differences in Food Craving and Obesity. Yale Journal of Biology and Medicine, 89(2), 161-173. i

Halim, N., R., and Iskanar, D. A. (2019). Pengaruh Kualitas Produk, Harga, dan Persaingan Terhadap Minat Beli Gula Merah. Jurnal Riset Manajemen dan Bisnis, 4(3), 415-424.

Kotler, P., and Armstrong, G. (2012). Marketing: An introduction. New Jersey: Prentice Hall.

Kukanja, M., Gomezelj, O. D., and Kodrič, B. (2016). Ensuring Restaurant Quality And Guests' Loyalty: An Integrative Model Based On Marketing (7P) Approach. Total Quality Management \& Business Excellence, 28(13), 1-17. i

Nugroho B.A., and Dewanto P. (2011). The Analysis of Marketing Mix Consided by The Consumers in Purchasing The Pasteurisasi Milk of The Dau Fresh Milk at Dau Vuc Malang. Jurnal Habitat, 22(1), 39-50.

Owomoyela, S. K., Oyeniyi, K. O., and Ola, O. S. (2013). Investigating The Impact Of Marketing Mix Elements On Consumer Loyalty: An Empirical Study On Nigerian Breweries Plc. Journal Contemporary Research in Business, 4(1), 485 - 496.

Pradana, A. (2017). Strategi Pengembangan UMKM Kawista di Kabupaten Rembang. Skripsi. Universitas Negeri Yogyakarta.

Purnamasari I., Anindita R., and Setyowati P.B. (2018). The Influence of Marketing Mix (Product, Price, Place, and Promotion) or Customer Statisaction Transform Into Customer Loyality on a Coldplay Juice Soji. Jurnal Habitat, 29(2), 57-64.

Purnomo, E. (2016). Pengaruh Harga, Kualitas Produk dan Lokasi Terhadap Minat Beli Konsumen Dalam Membeli Beras Lokal (Studi Kasus Desa Rambah Utama). Skripsi. Universitas Pasir Pengaraian.

Riyanto, S., and Hatmawan, A.A. (2020). Metode Riset Penelitian Kuantitatif Penelitian di
Bidang Manajemen, Teknik, Pendidikan, dan Eksperimen. Yogyakarta: Deepublish.

Rundh. (2010). The imulti-faceted Dimension of Packaging British Food. British Food Journal, 107(9), 607-684.

Saragih, R. (2012). Pengaruh Process dan Physical Evidence Terhadap Minat Beli Konsumen Dengan Price Sebagai Variabel Moderating (Studi Kasus Ayam Penyet Rahmat Jalan Letda Sujono Bandar Selamat). Skripsi. Universitas Islam Negeri Sumatera Utara.

Sims, R. (2010). Food, place and authenticity: local food and the sustainable tourism experience. Journal of Sustainable Tourism, 17(3), 321-336.

Wardani, H. (2015). Pengaruh Kualitas Produk dan Harga Terhadap Konsumen Muslim Jaizah Boutique Tlogosari Semarang. Skripsi. Universitas Islam Negeri Walisongo. 